\title{
HOW THE CULTIVATION OF WILD PLANTS IN BOTANIC GARDENS CAN CHANGE THEIR GENETIC AND PHENOTYPIC STATUS AND WHAT THIS MEANS FOR THEIR CONSERVATION VALUE
}

\author{
Andreas Ensslin ${ }^{1} \&$ Sandrine Godefroid ${ }^{2}$
}

\begin{abstract}
The discipline of horticulture, growing and propagating plants under artificial conditions, has a centuries-long tradition and has developed into a vital industry of breeding, propagating and trading ornamental and wild plants around the globe. Botanic gardens have always been at the centre of horticultural training and have provided excellence and advancements in the field. In recent decades, botanic gardens have also become an active part of ex situ conservation activities by storing seeds of endangered wild plants, growing living collections for conservation purposes, or propagating plants for direct reintroduction measures. While this shift in focus has been necessary and very important, ex situ collections of wild plants have been criticised for being genetically impoverished, potentially hybridised with congeners, or adapted to the artificial garden conditions and potentially having lost specific adaptations to their original wild habitat. In this review, we provide an overview of these potential threats to wild plants in ex situ living collections and outline examples of how ex situ cultivation can affect genetic diversity, trait expression and adaptive responses of the plants. We evaluate what these changes could mean for the conservation value of the collections, and discuss how they could be avoided by refining horticultural practices for wild plants.
\end{abstract}

\section{INTRODUCTION}

Botanic gardens have always been at the interface between horticulture and nature, as they grow and display the wealth and variety of the world's flora under artificial conditions. For centuries, botanic gardens have been centres of plant propagation and trade around the globe providing plants for agriculture, medicine and ornament. As well as plant trading, botanic gardens also have a long tradition of taxonomic research and botanical education (Donaldson, 2009; Heywood, 2011). With increasing recognition of the world's biodiversity crises, botanic gardens have expanded their focus to plant conservation by cultivating rare and endangered plants and supplying them for restoration and reintroduction programmes (Donaldson, 2009; Rae, 2011). This shift in focus has also shifted the tasks and responsibilities of botanic gardens to centres

\footnotetext{
1. Andreas Ensslin was previously a postdoctoral fellow at Botanic Garden Meise. He is currently a postdoc at the Botanical Garden of the University of Bern.

Address: Botanical Garden of the University of Bern, Altenbergrain 21, 3013 Bern, Switzerland.

Email: andreas.ensslin@boga.unibe.ch

2. Sandrine Godefroid is a conservation officer at Botanic Garden Meise, employed by the Fédération Wallonie-Bruxelles, Service général de l'Enseignement supérieur et de la Recherche scientifique, Brussels, Belgium.

Address: Nieuwelaan 38, 1860 Meise, Belgium.
} 
of conservation, preservation and education (Maunder, 1994). The conservation of threatened plants in botanic gardens (hereafter named ex situ conservation) has been widely acknowledged as a crucial contribution made by the botanic garden community to species conservation efforts worldwide (Wyse Jackson \& Sutherland, 2000; SCBD, 2010). The IUCN has recently revised its guidelines concerning ex situ conservation and plant reintroduction (IUCN/SSC, 2013, 2014), and in this review we use the terms 'plant reintroduction' and 'population reinforcement' according to the IUCN definitions for population restorations (IUCN/SSC, 2013).

Ex situ conservation is a programme to secure a species or population from extinction and to provide material for its re-establishment in the wild once the problems that have led to its being endangered in the wild have been overcome (Fig. 1). This can be accomplished in various ways, such as via living collections, seed banking or cryopreservation of tissue and embryos (Maunder et al., 2004a). Among these methods, living collections are the most common, as they connect to the core competence of each botanic garden, i.e. horticulture, while the other methods involve advanced technologies and expensive facilities. The idea of ex situ conservation is to preserve threatened plants in the botanic garden as they are in nature, hence conservation collections have to reflect the genetic and phenotypic status of the wild population they originate from (Schaal \& Leverich, 2004). While the genetic representation of ex situ collection is often most emphasised, the phenotypic representation, i.e.

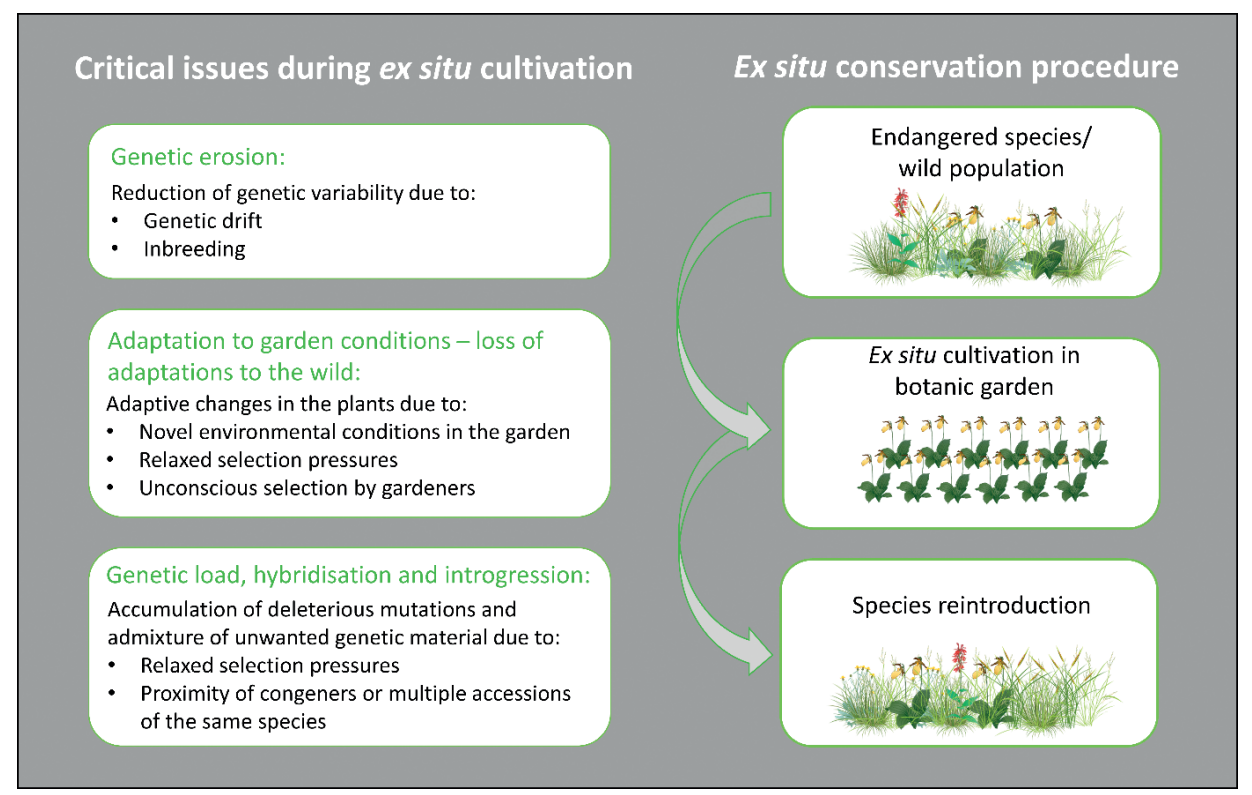

Fig. 1 Schematic overview of the concept of ex situ conservation of endangered plants via living collections in botanic gardens and the genetic problems arising from it. Images: Tracy Saxby \& Jane Hawkey, IAN Image Library (ian.umces.edu/imagelibrary). 
in germination, growth and reproductive traits, is equally important, as this is where natural selection operates (Vitt \& Havens, 2004). If cultivation of an endangered plant in a botanic garden results in a genetic change of the plant's phenotype away from the natural one, it means a departure from the basic idea of the ex situ collection and may have negative consequences for the use of the plants for conservation activities such as reintroductions and population reinforcements (Ensslin et al., 2015). As plants are also able to adjust their phenotype to environmental conditions (i.e. phenotypic plasticity), the distinction of genetically determined changes in the phenotype is therefore important, and we refer to phenotypic changes caused by genetic modifications throughout this article.

Changes in plant phenotypes due to cultivation and propagation by humans is a well-known phenomenon commonly referred to as domestication. Humans have cultivated plants for millennia and this influence has resulted in the evolution of many crop plants such as cereals and fruit and fibre crops, which can have a set of traits very different from their wild progenitors (Fuller \& Allaby, 2009; Meyer et al., 2012). The sets of traits, which are assumed to have convergently evolved due to human influence, have been called the domestication syndrome (Hammer, 1984). The domestication syndrome typically includes loss of seed dispersal and seed dormancy mechanisms, increase in size (whole plant size, flower size and seed size) and synchronisation of the phenological timing (Hammer, 1984; Zohary, 2004; Kluyver et al., 2017; Milla et al., 2017). While all these trait changes have resulted from an adaptive evolution in response to selection pressures due to human cultivation, there is a clear distinction between those traits which have changed due to direct selection by humans and those which have occurred as a byproduct of cultivation and harvesting procedures (Milla et al., 2015). Intentional selection, for example for yield, fruit size or palatability, is commonly called artificial selection, while, in contrast, the loss of seed dispersal and dormancy mechanisms is assumed to have occurred as a consequence of the harvesting methods and is thus called unconscious (or natural) selection (Heiser, 1988; Zohary, 2004; Fuller \& Allaby, 2009). Wild plant cultivation in botanic gardens may not primarily imply artificial selection, as yield does not play a role in ex situ conservation, but beauty and plant vigour may be traits which could be a result of artificial selection (Havens et al., 2004). However, botanic garden cultivation shares propagation and also to some degree harvesting practices used in agriculture, thus unconscious selection may play a much bigger role (Havens et al., 2004; Ensslin et al., 2015).

Horticulture is the art, science, technology and business of growing plants for human use (Wikipedia, 2018). In other words, a classic horticulturist aims to modify the characteristics of a plant in favour of humanity's needs, be they yield, beauty or medicine. This definition does, of course, have strong implications when horticulturists propagate plants for conservation purposes, as it is done in ex situ collections. A refinement of horticultural practices tailored to wild plant ex situ conservation seems desirable, as ex situ conservation integrates principles from horticulture, 
conservation biology and evolutionary ecology (Gratzfeld, 2017; Volis, 2017). Some larger botanic gardens have adopted this idea and developed special programmes to include ecological and evolutionary training in their horticultural formation (see Gratzfeld, 2017), but in many countries these developments are so far missing. Moreover, special guidelines for the ex situ plant conservation have been published in recent articles and textbooks (Hamilton \& Chorlton, 1996; Engelmann, 2002; Havens et al., 2004; Basey et al., 2015), and many countries have developed their own guidelines and recommendations in their respective languages (Belgium: Godefroid \& Ensslin, 2017; Germany: Lauterbach, 2013; Scotland: NSRF, 2018; Switzerland: InfoFlora, 2018).

However, in order to verify protocols and guidelines meant for conserving endangered plants in botanic gardens, one premise would be to understand what processes are acting in botanic garden collections and how horticultural methods influence the genetic and phenotypic status of the plants. To date, we are still far from a complete understanding of the effects of ex situ cultivation on wild plants (Ensslin et al., 2015). In this review, we give an overview of the knowledge available on the effects of cultivation on wild plant species and what this could mean for their value for reintroduction measures. We outline the steps of the propagation process where problems have been discovered and show their consequences on the genetic and phenotypic status of the plants. Furthermore, we discuss the implications for the use of the plant material for reintroduction measures and give recommendations on how to overcome those problems. We will hereby focus on the ex situ cultivation process taking place in the botanic gardens and leave out the step of the initial seed collection from the wild population. Although this is a crucial step in the establishment of ex situ plant collections, this topic has already been discussed extensively (Guerrant et al., 2004; ENSCONET, 2009; Hoban \& Schlarbaum, 2014). In contrast, we feel that the cultivation and regeneration procedure has been rather neglected so far.

\section{WEAK POINTS IN THE EX SITU CONSERVATION PROCEDURE}

The regeneration of plants in ex situ collections holds the key to the successful preservation of genetic and phenotypic diversity. This was realised early in the development of this concept, and when crop plants in seed banks were being established. For instance, Hamilton \& Chorlton (1996) refer to random genetic drift and selection as possible threats to the genetic integrity of seed bank collections, as do Knapp \& Rice (1994) when describing the optimal methods for seed propagation for grassland revegetation programmes. Schoen \& Brown (2001) elaborate on these issues, showing that genetic erosion is likely, particularly when ex situ collections are very small and isolated from genetic exchange. Likewise, introgression of maladapted genetic material, either from congeners (hybridisation) or from other populations of the same species (different accessions), has also been discovered as a potential risk to the genetic integrity of the ex situ collections (Maunder et al., 2004b). 


\section{Genetic erosion via genetic drift and inbreeding}

Genetic drift (the change of allele frequencies due to stochastic events) is seen as a major challenge for preserving genetic diversity in ex situ collections over time. This is because genetic drift reduces genetic diversity as a function of population size, which means that the smaller a population is, the more negative is the influence of genetic drift on its genetic diversity. Inbreeding, i.e. the mating of related individuals, can intensify this negative process and can also directly lead to a decrease of plant vitality and fitness via inbreeding depression. In contrast to genetic drift, inbreeding is not dependent solely on the population size of the collection, but also on the mating strategy and pollination mode of the species. For instance, the harmful effects of inbreeding are stronger in outbreeding species and particularly strong in self-incompatible species but, on the other hand, outbreeding depression is more likely to occur in predominantly selfing species (Frankham et al., 2017). However, the natural inbreeding rate of most wild plant species is not known and neither is their response to inbreeding under ex situ conditions.

Genetic erosion is important, because it threatens a major aim of ex situ collections: to hold genetic representation of the wild population. Several studies with rare and endangered species have found genetic under-representation in the garden collection and divergence from the wild origin population (Namoff et al., 2010; Rucinska \& Puchalski, 2011; Lauterbach et al., 2012). Ensslin et al. (2011) showed that genetic diversity of Cynoglossum officinale populations in botanic gardens decreased with the increasing age of the collections. In particular, short-lived species are likely to be genetically impoverished in ex situ collections, as shown by Brütting et al. (2013), a finding which clearly points to genetic drift as a driver behind these patterns. However, whether the strong negative drift effects on genetic diversity also have negative consequences for variability in phenotypic traits is an important yet unanswered question (Vitt \& Havens, 2004).

\section{Adaptation to the botanic garden conditions and loss of adaptations to conditions in the natural habitat}

When wild plants are grown in botanic gardens, the novel garden conditions impose new selection pressures on them and favour adapted over maladapted genotypes, resulting in evolutionary adaptation over time. Hence, it is almost unavoidable that plants will eventually adapt to the environmental conditions of the garden; this is a logical consequence of the difference in conditions between the original habitat and their new ex situ habitat (Husband \& Campbell, 2004). Moreover, previous studies have shown that adaptive evolution can occur within a very short time and only a few generations (Carroll et al., 2007). Hence, evolutionary theory strongly predicts adaptive changes in ex situ plant collections.

Probably the most compelling example of trait changes as a consequence of changed selection pressures in botanic gardens is the loss of seed dormancy. Loss of seed dormancy belongs to the set of traits strongly influenced by crop domestication (Fuller 
\& Allaby, 2009) and is therefore likely to be affected by ex situ cultivation too. Increase in germination rates and loss of dormancy have been found in several studies with wild plants cultivated in botanic gardens, or in commercial nurseries for ecological restoration programmes (Ensslin et al., 2011; Schröder \& Prasse, 2013a). In a recent database analysis, Ensslin et al. (2018) found a marked decrease in seed dormancy in seeds across 22 short-lived plant species from plants that had been cultivated in the Botanic Garden Meise (BG Meise) compared to seeds that had been directly collected from the wild. Changes in germination characteristics can happen very quickly, even within just a few generations, as shown for common plants in native seed production nurseries (Schröder et al., 2013) and for rare and threatened plants cultivated for ex situ conservation in botanic gardens (Rauschkolb, 2017).

Besides changes in germination characters, very few studies have investigated other types of change, such as those relating to phenology, growth and reproduction. Existing studies have so far focused on cultivars used for ecological restoration and have found some, albeit not consistent, indications of increased growth rates and competitive ability in the cultivars compared to their wild relatives (Klopf \& Baer, 2011; Schröder \& Prasse, 2013b; Walker et al., 2014; Herget et al., 2015; Dyer et al., 2016). In botanic garden plants, two studies found some differences in plant architecture and phenology between wild and garden plants (Ensslin et al., 2011; Ensslin et al., 2015), but more comprehensive studies across many species are missing.

Besides the risk of adapting to the garden environment, there is also the concern that species cultivated ex situ could lose important stress adaptations to their wild habitat, as environmental stress is typically neutralised in the ex situ environment. These stress adaptations could involve adaptations to drought, lack of nutrients, interspecific competition, herbivory and pathogen infection (Husband \& Campbell, 2004; Ensslin et al., 2015). Because of the relaxed selection regimes in the ex situ collection (meaning that mortality due to those stresses is largely prevented), the loss of these stress adaptations may only become apparent when the species is reintroduced into its natural habitat. Despite the potential importance of stress adaptations for the value of ex situ collections, their loss has rarely been investigated in ex situ collections of threatened plants (but see Rauschkolb, 2017).

In an experimental study at the BG Meise, we sought to increase our understanding of trait shifts and loss of stress responses during ex situ cultivation of wild plants. We did this by comparing the phenology, growth and reproductive traits of ten herbaceous European plant species, which had been cultivated for a period of ten to thirty years in the ordinary garden beds at the BG Meise with plants sampled near to where the original collections were made. The plants were grown in pots under the same conditions in an experimental site in the BG Meise, and half of the plants were subjected to severe drought stress during summer 2016 (Fig. 2a, b). Because the ten species naturally differed in drought tolerance, we grouped them into five drought-tolerant and five drought-intolerant species according to their Ellenberg moisture indicator values. The full analyses of this experiment will be published in more detail elsewhere, but because 


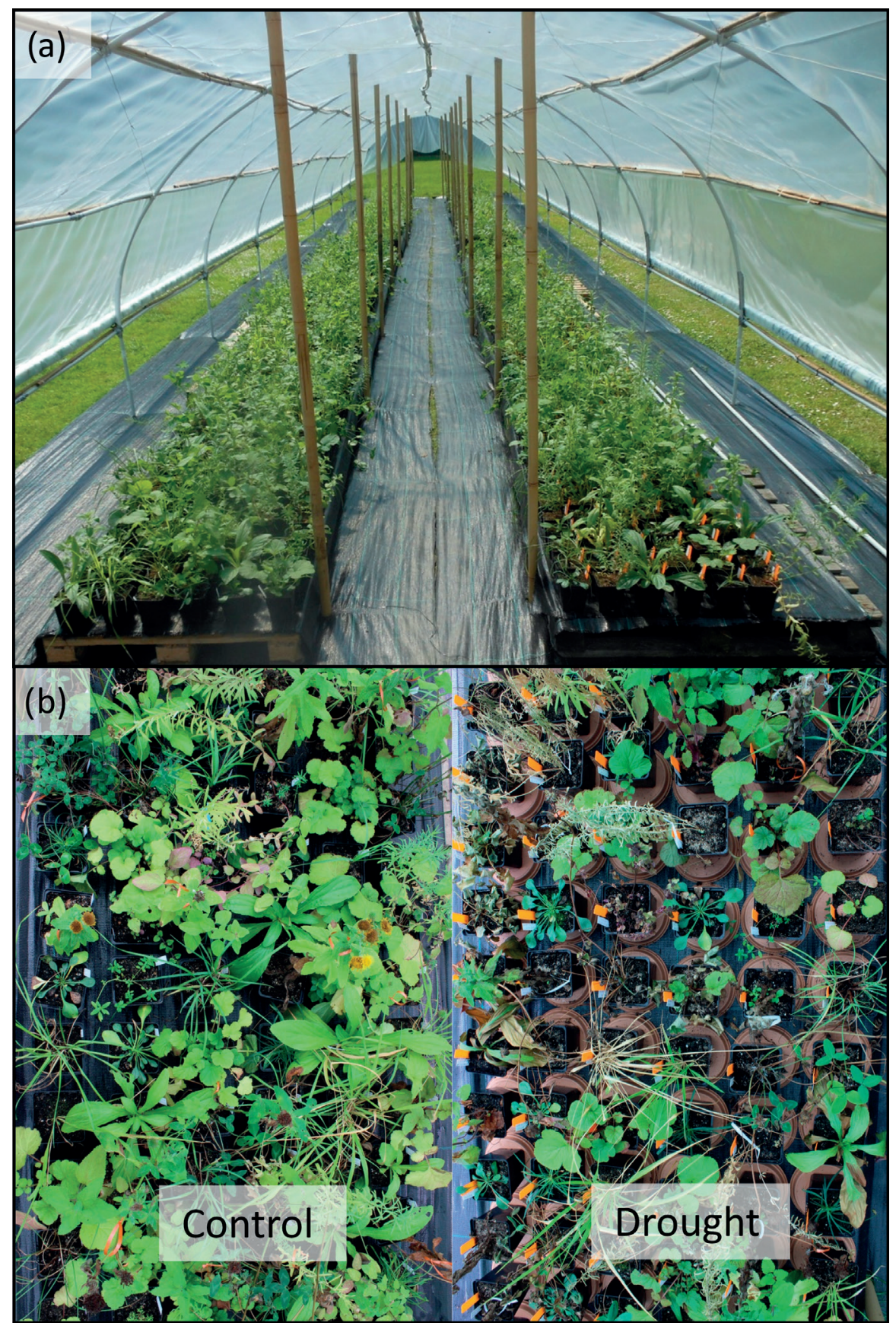

Fig. 2 (a) The multi-species common garden experiment conducted at the BG Meise. The traits of ten species collected from the botanic garden beds were compared with those collected directly from wild populations. (b) The effects of two three-week periods of drought stress applied to half of the plants to investigate differences in stress response among garden and wild plants. Photos: A. Ensslin. 
this experiment is particularly relevant for this article, we shall give a brief preview of the results of the experiment below.

As previously found in many other species (see Ensslin et al., 2018), garden plants had an increased germination rate compared to their wild counterparts in our experiment (Fig. 3). However, other trait shifts in garden-cultivated plants were not consistent and depended on the trait and whether the plant was considered stress-tolerant or stressintolerant. For instance, while drought-intolerant, garden-cultivated species flowered slightly earlier and produced more flowering stems than the wild plants, drought-tolerant garden plants flowered at similar times and produced fewer flowering stems, but did not grow as tall as their wild counterparts (Fig. $4 a-c)$. Drought stress generally caused higher mortality and reduced biomass production in surviving plants. In droughttolerant species, however, drought stress affected the mortality only in the garden plants, indicating loss of drought stress adaptations to some degree (Ensslin, unpublished data).

Our experiment at the BG Meise and the conclusions from the recent studies mentioned above suggest that differences between garden-cultivated and wild plants are very dependent on the trait in question and the functional group of the plant (i.e. its ecology). For traits where strong directional selection can be assumed, for instance germination traits, consistent shifts in trait can be expected across many species (Ensslin et al., 2018). However, for other traits such as growth performance, reproduction or

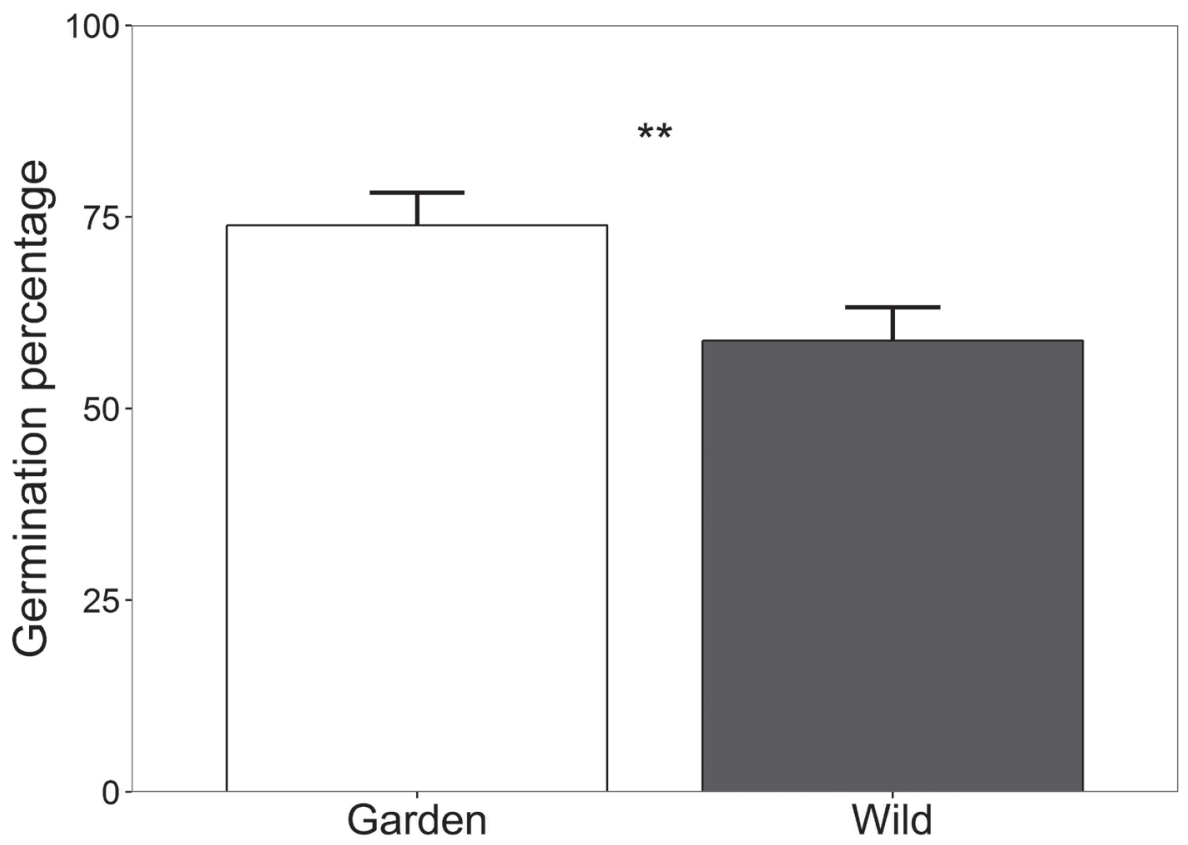

Fig. 3 Germination percentage of ten species either cultivated in the BG Meise for at least ten years or directly collected from wild populations in Belgium.

** $\mathrm{P}<0.01$. The error bars are standard errors of the mean. 

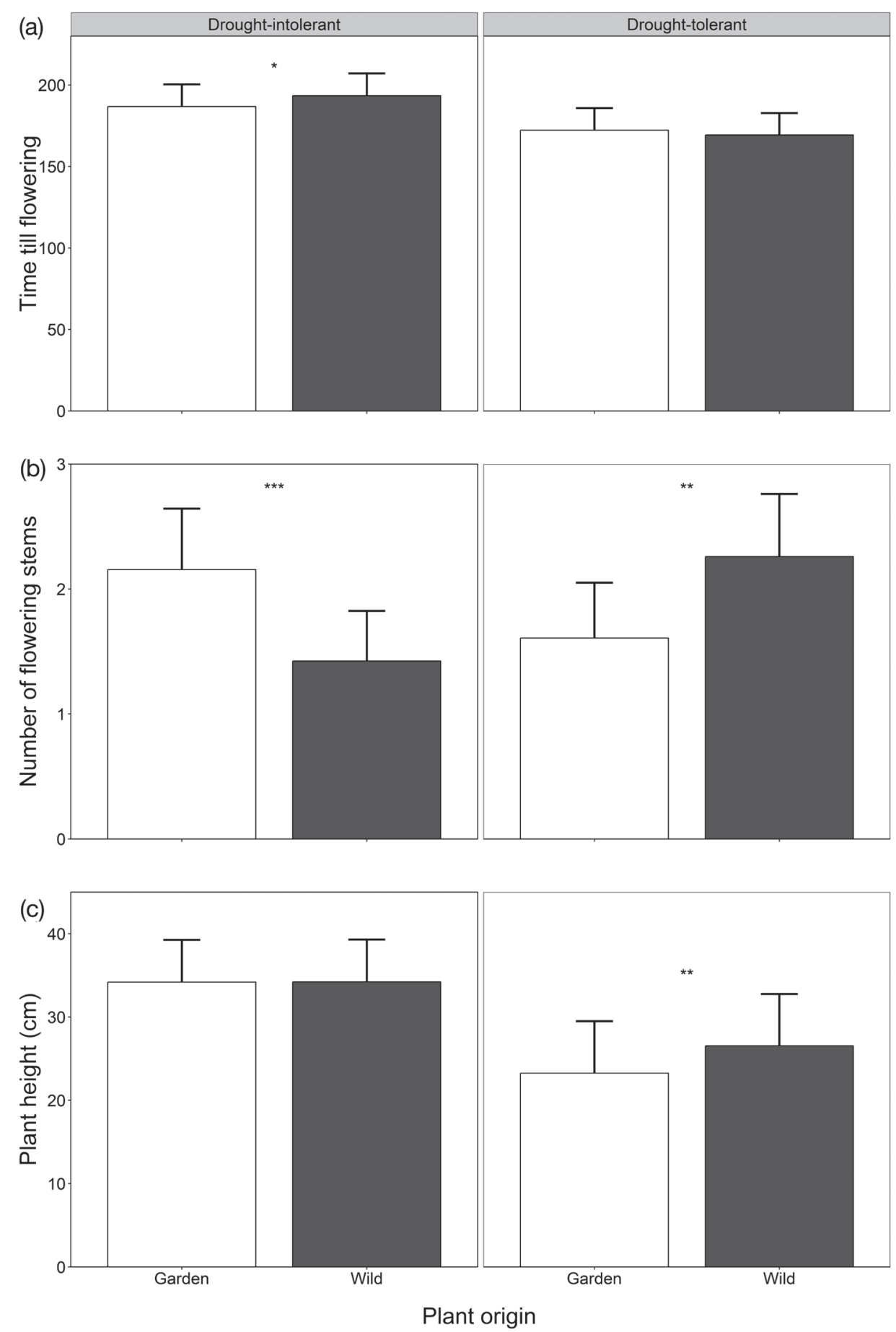

Fig. 4 Difference in traits of garden-cultivated and wild plants of ten species grown in a multi-species experiment in the BG Meise, separated by whether they are drought tolerant or not. The stars denote significant differences between garden and wild plants in the drought-tolerant or drought-intolerant species subgroups. *: $\mathrm{P}<0.05, * *: \mathrm{P}<0.01, * * *: \mathrm{P}<0.001$. The error bars are standard errors of the mean. 
phenology, selection might be less consistent and so trait expression in garden-cultivated plants may be more influenced by random processes such as genetic drift (see also Ensslin et al., 2015). While this does not necessarily mean that selection does not operate on these traits, strong drift effects may offset selection effects in the small garden populations (Willi et al., 2006). For instance, while selection by gardeners could favour larger and stronger plants with bigger flowers and seeds, genetic drift and inbreeding can reduce genetic diversity and thereby fitness measures such as growth and seed size. Hence, depending on which effects dominate, plant traits can change in either direction, and an evolution of ex situ plants towards the domestication syndrome is not clearly visible thus far.

\section{Mutation accumulation, hybridisation and genetic introgression}

The reduced pressure of natural selection is not only a problem because of the risk of losing important stress adaptations. Deleterious alleles (variations of genes that reduce fitness), created by new mutations or by inbreeding, can accumulate because they are not out-selected as they would be in the natural habitat (Schoen et al., 1998; Havens et al., 2004). In a similar way to the lost stress adaptations, these processes could strongly decrease the plants' performance when they are subjected to their natural conditions, that is, when they are reintroduced into the wild.

Another problem is unwanted gene flow into the ex situ population, either by hybridisation (cross-pollination with another species; e.g. Zhang et al., 2010) or by introgression (cross-pollination with another population of the same species; e.g. Keller et al., 2000). Both processes undermine the ex situ strategy (genetic representation of the wild population) and thereby compromise the value of the collection. Hybridisation is particularly dangerous as, on the one hand, it can lead to sterile offspring, therefore threatening the persistence of the population. On the other hand, hybrids are known to have unique abilities and a number of notorious invasive plants resulted from hybridisations in botanic gardens (Maunder et al., 2004b). In the case of introgression, it should be kept in mind that this risk considers not only cross-pollination between two accessions of the same species in the botanic garden, but also cross-pollination between the ex situ collection and nearby wild populations (possibly threatening both the wild and the ex situ collection). To prevent introgression and hybridisation in ex situ collections of endangered plants, accessions and genera with known hybridisation problems should be kept far enough apart (from several hundred metres up to a few kilometres; Greenleaf et al., 2007; Basey et al., 2015) to prevent cross-pollination.

WHAT IMPLICATIONS DOES THE USE OF EX SITU RAISED PLANTS HAVE FOR REINTRODUCTION PROGRAMMES?

Ex situ conservation of endangered plants in botanic gardens or in seed banks is not an end in itself. In order to effectively improve the prospects of a threatened species, it must 
be accompanied with efforts to improve the species' situation in its natural habitat, for example via reintroduction or reinforcement measures. However, plant reintroduction is a complex discipline and currently too many reintroductions fail, in many cases without a subsequent assessment of the reasons for the failure. In two recent reviews, a poor choice of reintroduction site, the use of inappropriate management regimes and introduction techniques, and genetically impoverished material with high mortality due to stress events were given as the most significant reasons for the failure of an reintroduction (Godefroid et al., 2011; Dalrymple et al., 2012). Most of these reasons are, however, more guesswork than tested hypotheses (Dalrymple et al., 2012), making robust recommendations difficult. This shows on the one hand the large knowledge gap that still exists in determining the crucial influences of reintroduction success. On the other hand, it also underlines the importance of using only best-suited ex situ material for reintroduction measures, so that at least genetic reasons for failure or success can be excluded.

Very little is known about how changes during ex situ cultivation could affect reintroduction success. However, in the science of animal reintroductions, a large body of evidence shows that changes in animal traits during their captivity can have serious negative implications for reintroduction programmes (reviews by Williams \& Hoffman, 2009; Witzenberger \& Hochkirch, 2011). For instance, studies on supportive breeding of fish showed that not only are genetically altered genotypes less fit in the wild, but they can also introduce their maladapted genes into the native gene pool and thereby further reduce the fitness of the local populations (Araki et al., 2009). In plants, some studies have been conducted in the USA on cultivars used for restoration and revegetation. These are wild plants that have been bred for some time by seed-producing companies and are then sold to farmers and conservationists for revegetation programmes. These cultivars, which showed high vigour and more effective nutrient uptake than the wild genotypes, had no consistent effect on community composition and development, or ecosystem functioning when used in experimental revegetations, compared to when local wild genotypes were used (Baer et al., 2013; Willand et al., 2015). This might suggest that the impact of the observed changes in cultivars on community and ecosystem dynamics is not as strong as suspected, but the authors themselves are very cautious about their conclusions of the studies and acknowledge the large knowledge gap that still exists in the field. We are not aware of any comparative published study testing the effect of changes in plants due to botanic garden cultivation on their establishment and persistence when reintroduced into the wild. Besides the implications of genetically altered plants for the persistence of the reintroduced population, there is also a certain risk of introducing pathogens or parasites into the wild together with the ex situ reared plants, particularly if plants have lost resistance against these antagonists during cultivation. Hence, checking the plant material carefully for pathogens before it is brought back into nature should be a standard in every introduction protocol (Frachon, 2013). 


\section{HOW CAN BOTANIC GARDENS AVOID GENETIC CHANGES IN THEIR}

\section{COLLECTIONS?}

So what does this mean for botanic gardens and their gardeners? While the consequences of genetic changes during cultivation are largely unknown, the precautionary principle would be to avoid them if possible. However, fighting plant trait changes in ex situ collections seems daunting considering their multiple causes and almost inevitable evolutionary reasoning. Nevertheless, there are a few strategies which can help to mitigate the negative effects of cultivation (Table 1).

\section{How can genetic erosion in ex situ collections be prevented?}

The answer to this lies above all in the size of the plant collection. As the effective population size, i.e. the number of individuals that really contribute to the next generation, is the key factor that determines the magnitude of genetic erosion via genetic drift, increasing the population size is the easiest way of reducing the risk of genetic erosion in the ex situ collection. However, pinpointing this to an exact number of plants that are needed to avoid inbreeding and genetic drift is difficult as it depends on the species' characteristics such as mating type and reproductive strategy (Basey et al., 2015; Ensslin et al., 2015). Recently, Frankham et al. (2014) revised their recommendations for effective population sizes to 100 individuals to prevent inbreeding, and 1,000 individuals to maintain evolutionary potential (i.e. prevent genetic drift). While garden space and working load clearly impose limits on the implementation of these guidelines, they still provide a clue to the order of magnitude of an ideal ex situ collection (see also Table 1). To facilitate natural outcrossing rates in ex situ collections, promising results have been

\begin{tabular}{|l|l|l|}
\hline \multicolumn{1}{|c|}{ Problem } & \multicolumn{1}{|c|}{ Effect } & \multicolumn{1}{c|}{ Counteraction } \\
\hline Genetic drift & $\begin{array}{l}\text { Loss of genetic diversity, loss } \\
\text { of rare alleles, fixation of } \\
\text { deleterious alleles }\end{array}$ & $\begin{array}{l}\text { Large effective population sizes } \\
\text { (more than 500 individuals), } \\
\text { frequent introduction of new } \\
\text { genetic material }\end{array}$ \\
\hline Inbreeding & $\begin{array}{l}\text { Reduction of genetic diversity, } \\
\text { increase of homozygosity, } \\
\text { inbreeding depression }\end{array}$ & $\begin{array}{l}\text { Increase population sizes (more } \\
\text { than 100 individuals), controlled } \\
\text { pollinations }\end{array}$ \\
\hline $\begin{array}{l}\text { Adaptation to the garden } \\
\text { conditions - loss of adaptations } \\
\text { to the wild }\end{array}$ & $\begin{array}{l}\text { Genetic changes in traits, } \\
\text { reduction of trait variability }\end{array}$ & $\begin{array}{l}\text { Equalise contribution of mother } \\
\text { and father to the next generation, } \\
\text { simulate original habitat, reduce } \\
\text { cultivation time }\end{array}$ \\
\hline $\begin{array}{l}\text { Mutation accumulation, } \\
\text { hybridisation, introgression }\end{array}$ & $\begin{array}{l}\text { Fixation of genetic load, loss of } \\
\text { genetic integrity }\end{array}$ & $\begin{array}{l}\text { Simulate original habitat, } \\
\text { avoid multiple species of } \\
\text { hybridisation-prone genera, } \\
\text { separate accessions spatially }\end{array}$ \\
\hline
\end{tabular}

Table 1 Strategies to prevent genetic changes in ex situ collections. 
achieved with temporary placements of bumblebee colonies into the living collections (Andreas Titze, pers. comm.).

\section{How can adaptation to the botanic garden conditions be prevented?}

Adaptive evolution of cultivated plants can only happen when a few genotypes contribute much more to the next generation than most other genotypes. Hence, a logical idea is to equalise the male and female contributions to the next generation (Schoen \& Brown, 2001; Havens et al., 2004). However, this means that gardeners would have to make sure that each male flower (or plant) pollinates an equal number of female individuals in the population, which they could only do by performing the pollinations themselves. While this is usually beyond the means of the staff of a botanic garden, making sure that all mother plants are sampled for producing the next generation would be a big step in the right direction (Ensslin et al., 2015). Planting out both early and late germinating seedlings avoids selection on reduced seed dormancy (Basey et al., 2015).

Another possibility which is frequently discussed is the reduction of the difference in selective forces between the natural and the ex situ environment. This approach is called quasi in situ or inter situ (Volis \& Blecher, 2010). This is the plausible idea that, if natural habitats are mimicked in some way in the garden or a species is planted in a natural habitat that can be managed in some way to ensure the survival of the planted species, adaptation to ex situ conditions would not happen, or would do so only very slowly. While this approach seems intriguing, studies about its effectiveness in preventing genetic changes and adaptation processes are lacking. Mixed conclusions come from the only available genetic study, where Müller et al. (2017) investigated whether four species conserved for more than thirty years in a small, artificially created steppe area in a botanic garden in Germany did genetically diverge from the natural source population close by. They found that some of the species did not show a detectable genetic differentiation, while others significantly differentiated from the original source population over these 30 years. Their results, therefore, can neither strongly support nor disqualify the concept. In any case, it shows that mimicking natural habitats in botanic gardens is not a trivial venture and should be done with all knowledge and resources available to ensure that such investments pay off.

In general, limiting the number of generations plants are kept ex situ to a minimum will always be the best strategy to prevent any evolutionary change (Schoen \& Brown, 2001; Havens et al., 2004). This will obviously be more important for the management of short-lived species than for long-lived ones such as trees. Some British seed supply companies recommend the cultivation of plants for no more than five generations (Walker et al., 2004), and Schoen \& Brown (2001) suggest that six regeneration cycles is a reasonable number. German conservation guidelines seem to be more specific in that they take into account the life form, advocating the rule of a maximum of two generations for woody species, four generations for herbaceous perennial species and five generations for annual and biennial species (Prasse et al., 2010). 


\section{FINAL REMARKS}

Ex situ conservation of endangered plants in botanic gardens is a crucial strategy to prevent species loss. The importance of living collections in botanic gardens will increase, particularly for endangered tropical species, as their seeds are in many cases desiccation-sensitive and thus cannot be dried and frozen in seed banks. Consequently, an optimisation of both cultivation and storage processes in botanic gardens in order to ensure proper maintenance of wild plant collections is paramount.

We have provided an overview of the current knowledge of the processes acting in ex situ collections in botanic gardens and discussed potential implications for plant reintroductions. We would like to emphasise that our review is not exhaustive and large knowledge gaps still exist in the field of ex situ conservation and plant reintroduction research. At the same time, it is clear that conservation programmes need to continue, and decisions about how to conserve plants in botanic gardens have to be made according to current knowledge. We hope that with this review, we will raise awareness of the threats to wild plants that can arise in botanic gardens' cultivation beds. In our view, curators and gardeners need to be aware of these and should acknowledge the distinction between collections with ex situ conservation value and ordinary display collections. We advise that cultivation standards are applied in accordance with the guidelines referred to here, at least to those collections where a conservation purpose cannot be excluded. This will definitely involve greater input from botanic garden staff and the revision of some basic propagation procedures, but it is urgently needed if botanic gardens want to keep their pivotal role in ex situ plant conservation.

\section{ACKNOWLEDGEMENTS}

We are grateful to Kate Hughes for the invitation to write this article for Sibbaldia. We would also like to thank Thierry Vanderborght, Sarah Le Pajolec, Ann Van de Vyver, Filip Vandelook, Hubert Lekeux and Francis Hanssens for their help with the experiment. An anonymous reviewer provided very helpful comments on the manuscript. Andreas Ensslin was supported by the Swiss National Science Foundation (grant number P2BEP3_165405).

\section{REFERENCES}

ARAKI, H., COOPER, B. \& BLOUIN, M.S. (2009). Carry-over effect of captive breeding reduces reproductive fitness of wild-born descendants in the wild. Biology Letters, 5(5): $621-624$.

BAER, S.G., GIBSON, D.J., GUSTAFSON, D.J., BENSCOTER, A.M., REED, L.K., CAMPBELL, R.E., KLOPF, R.P., WILLAND, J.E. \& WODIKA, B.R. (2013). No effect of seed source on multiple aspects of ecosystem functioning during ecological restoration: Cultivars compared to local ecotypes of dominant grasses. Evolutionary Applications, 7(2): 323-335. 
BASEY, A.C., FANT, J.B. \& KRAMER, A.T. (2015). Producing native plant materials for restoration: 10 rules to collect and maintain genetic diversity. Native Plants Journal, 16(1): $37-53$.

BRÜTTING, C., HENSEN, I. \& WESCHE, K. (2013). Ex situ cultivation affects genetic structure and diversity in arable plants. Plant Biology, 15(3): 505-513.

CARROLL, S.P., HENDRY, A.P., REZNICK, D.N. \& FOX, C.W. (2007). Evolution on ecological time-scales. Functional Ecology, 21(3): 387-393.

DALRYMPLE, S.E., BANKS, E., STEWART, G.B. \& PULLIN, A.S. (2012). A meta-analysis of threatened plant reintroductions from across the globe. In: MASCHINSKI, J. \& HASKINS, K.E. (eds) Plant Reintroduction in a Changing Climate: Promises and Perils. Island Press, Washington, DC, pp. 31-50.

DONALDSON, J.S. (2009). Botanic gardens science for conservation and global change. Trends in Plant Science, 14(11): 608-613.

DYER, A.R., KNAPP, E.E. \& RICE, K.J. (2016). Unintentional selection and genetic changes in native commercial seed production. Ecological Restoration, 34(1): 39-48.

ENGELMANN, F. (2002). Technologies and strategies for $e x$ situ conservation. In: ENGELS, J.M.M., RAMANATHA RAO, V., BROWN, A.H.D. \& JACKSON, M.T. (eds) Managing Plant Genetic Diversity. IPGRI, Rome, pp. 89-104..

ENSCONET (2009). ENSCONET Seed Collecting Manual for Wild Species. European Native Seed Conservation Network.

ENSSLIN, A., SANDNER, T.M. \& MATTHIES, D. (2011). Consequences of ex situ cultivation of plants: Genetic diversity, fitness and adaptation of the monocarpic Cynoglossum officinale L. in botanic gardens. Biological Conservation, 144(1): 272-278.

ENSSLIN, A., TSCHÖPE, O., BURKART, M. \& JOSHI, J. (2015). Fitness decline and adaptation to novel environments in ex situ plant collections: Current knowledge and future perspectives. Biological Conservation, 192: 394-401.

ENSSLIN, A., VAN DE VYVER, A., VANDERBORGHT, T. \& GODEFROID, S. (2018). Ex situ cultivation entails high risk of dormancy loss on short-lived wild plant species. Journal of Applied Ecology, 55(3): 1145-1154.

FRACHON, N. (2013). Plant health protocols for the reintroduction of native plants. Sibbaldia, 11: 53-60.

FRANKHAM, R., BALLOU, J.D., RALLS, K., ELDRIDGE, M., DUDASH, M.R., FENSTER, C.B., LACY, R.C. \& SUNNUCKS, P. (2017). Genetic Management of Endangered Plant and Animal Populations. Oxford University Press, Oxford.

FRANKHAM, R., BRADSHAW, C.J.A. \& BROOK, B.W. (2014). Genetics in conservation management: Revised recommendations for the 50/500 rules, Red List criteria and population viability analyses. Biological Conservation, 170: 56-63.

FULLER, D.Q. \& ALLABY, R. (2009). Seed dispersal and crop domestication: Shattering, germination and seasonality in evolution under cultivation. Annual Plant Reviews, 38: 238-295.

GODEFROID, S. \& ENSSLIN, A. (2017). Herintroductie van plantensoorten: een toekomstgerichte instandhoudingsmaatregel. Natuur Focus, 16(1): 32-40. 
GODEFROID, S., PIAZZA, C., ROSSI, G., BUORD, S., STEVENS, A.-D., AGURAIUJA, R., COWELL, C., WEEKLEY, C.W., VOGG, G., IRIONDO, J.M., JOHNSON, I., DIXON, B., GORDON, D., MAGNANON, S., VALENTIN, B., BJUREKE, K., KOOPMAN, R., VICENS, M. ... \& VANDERBORGHT, T. (2011). How successful are plant species reintroductions? Biological Conservation, 144(2): 672-682.

GRATZFELD, J. (2017). What is conservation horticulture? BG Journal, 14(2): 14-17.

GREENLEAF, S.S., WILLIAMS, N.M., WINFREE, R. \& KREMEN, C. (2007). Bee foraging ranges and their relationship to body size. Oecologia, 153(3): 589-596.

GUERRANT, E.O., FIEDLER, P.L., HAVENS, K. \& MAUNDER, M. (2004). Revised genetic sampling guidelines for conservation collections of rare and endangered plants. In: Ex Situ Plant Conservation: Supporting Species Survival in the Wild. Island Press, Washington, DC, pp. 419-441.

HAMILTON, N.R.S. \& CHORLTON, K.H. (1996). Regeneration of accessions in seed collections: A decision guide. In: ENGELS, J. (ed.) Handbook for Genebanks. International Plant Genetic Resources Institute, Rome.

HAMMER, K. (1984). Das Domestikationssyndrom. Die Kulturpflanze, 32(1): 11-34.

HAVENS, K., GUERRANT, E.O., MAUNDER, M. \& VITT, P. (2004). Guidelines for ex situ conservation collection management. Minimizing risks. In: GUERRANT, E.O., HAVENS, K. \& MAUNDER, M. (eds) Ex Situ Plant Conservation: Supporting Species Survival in the Wild. Island Press, Washington, DC, pp. 454-473.

HEISER, C.B. (1988). Aspects of unconscious selection and the evolution of domesticated plants. Euphytica, 37(1): 77-81.

HERGET, M.E., HUFFORD, K.M., MUMMEY, D.L. \& SHREADING, L.N. (2015).

Consequences of seed origin and biological invasion for early establishment in restoration of a North American grass species. PLoS One, 10, e0119889.

HEYWOOD, V.H. (2011). The role of botanic gardens as resource and introduction centres in the face of global change. Biodiversity and Conservation, 20(2): 221-239.

HOBAN, S. \& SCHLARBAUM, S. (2014). Optimal sampling of seeds from plant populations for ex-situ conservation of genetic biodiversity, considering realistic population structure. Biological Conservation, 177: 90-99.

HUSBAND, B.C. \& CAMPBELL, L.G. (2004). Population responses to novel environments: Implications for ex situ plant conservation. In: GUERRANT, E.O., HAVENS, K. \& MAUNDER, M. (eds) Ex Situ Plant Conservation: Supporting Species Survival in the Wild. Island Press, Washington, DC, pp. 231-285.

INFOFLORA (2018). Empfehlungen zur ex situ-Erhaltung und Ansiedlung gefährdeter Pflanzen. Available online: www.infoflora.ch/de/assets/content/documents/Ex-situ_ Introduction_D_F_I/InfoFlora_Empfehlungen_Ansiedlung.pdf (accessed April 2018).

IUCN/SSC (2013). Guidelines for reintroductions and other conservation translocations. Available online: https://portals.iucn.org/library/sites/library/files/documents/2014-064.pdf (accessed April 2018).

IUCN/SSC (2014). Guidelines on the use of ex situ management for species conservation. Available online: https://portals.iucn.org/library/node/44952 (accessed April 2018).

KELLER, M., KOLLMANN, J. \& EDWARDS, P.J. (2000). Genetic introgression from distant 
provenances reduces fitness in local weed populations. Journal of Applied Ecology, 37(4): $647-659$.

KLOPF, R.P. \& BAER, S.G. (2011). Root dynamics of cultivar and non-cultivar population sources of two dominant grasses during initial establishment of tallgrass prairie. Restoration Ecology, 19(1): 112-117.

KLUYVER, T.A., JONES, G., PUJOL, B., BENNETT, C., MOCKFORD, E.J., CHARLES, M., REES, M. \& OSBORNE, C.P. (2017). Unconscious selection drove seed enlargement in vegetable crops. Evolution Letters, 1(2): 1-9.

KNAPP, E.E. \& RICE, K.J. (1994). Starting from seed: Genetic issues in using native grasses for restoration. Restoration \& Management Notes, 12(1): 40-45.

LAUTERBACH, D. (2013). Ex situ-Kulturen gefährdeter Wildpflanzen-Populationsgenetische Aspekte und Empfehlungen für Besammlung, Kultivierung und Wiederausbringung. Anliegen Natur, 35(2): 32-39.

LAUTERBACH, D., BURKART, M. \& GEMEINHOLZER, B. (2012). Rapid genetic differentiation between ex situ and their in situ source populations: An example of the endangered Silene otites (Caryophyllaceae). Botanical Journal of the Linnean Society, 168(1): 64-75.

MAUNDER, M. (1994). Botanic gardens: Future challenges and responsibilities. Biodiversity and Conservation, 3(2): 97-103.

MAUNDER, M., HAVENS, K., GUERRANT, E.O. \& FALK, D.A. (2004a). Ex situ methods: A vital but underused set of conservation resources. In: GUERRANT, E.O., HAVENS, K. \& MAUNDER, M. (eds) Ex Situ Plant Conservation: Supporting Species Survival in the Wild. Island Press, Washington, DC, pp. 3-20.

MAUNDER, M., HUGHES, C., HAWKES, J.A. \& CULHAM, A. (2004b). Hybridization in $e x$ situ plant collections: Conservation concerns, liabilities and opportunities. In: GUERRANT, E.O., HAVENS, K. \& MAUNDER, M. (eds) Ex Situ Plant Conservation: Supporting Species Survival in the Wild. Island Press, Washington, DC, pp. 325-364.

MEYER, R.S., DUVAL, A.E. \& JENSEN, H.R. (2012). Patterns and processes in crop domestication: An historical review and quantitative analysis of 203 global food crops. New Phytologist, 196(1): 29-48.

MILLA, R., GARC, P. \& MATESANZ, S. (2017). Looking at past domestication to secure ecosystem services of future croplands. Journal of Ecology, 105(4): 885-889.

MILLA, R., OSBORNE, C.P., TURCOTTE, M.M. \& VIOLLE, C. (2015). Plant domestication through an ecological lens. Trends in Ecology and Evolution, 30(8): 463-469.

MÜLLER, C.M., HUWE, B., WISSEMANN, V., JOSHI, J. \& GEMEINHOLZER, B. (2017). Conservation genetic assessment of four plant species in a small replica of a steppe ecosystem >30 years after establishment. Biodiversity and Conservation, 26 (11): 26992716.

NAMOFF, S., HUSBY, C.E., FRANCISCO-ORTEGA, J., NOBLICK, L.R., LEWIS, C.E. \& GRIFFITH, M.P. (2010). How well does a botanical garden collection of a rare palm capture the genetic variation in a wild population?. Biological Conservation, 143(5): 1110-1117.

NSRF (National Species Reintroduction Forum) (2018). The Scottish code for conservation translocations: Best practice guidelines for conservation translocations in Scotland. Available 
online: www.gwct.org.uk/media/406156/Scottish-Code-for-Conservation-Translocations.pdf (accessed April 2018).

PRASSE, R., KUNZMANN, D. \& SCHRÖDER, R. (2010). Entwicklung und praktische Umsetzung naturschutzfachlicher Mindestanforderungen an einen Herkunftsnachweis für gebietseigenes Wildpflanzensaatgut krautiger Pflanzen Abschlussbericht. Deutsche Bundesstiftung Umwelt. Available online: https://www.dbu.de/OPAC/ab/DBUAbschlussbericht-AZ-23931.pdf (accessed April 2018).

RAE, D. (2011). Fit for purpose: The importance of quality standards in the cultivation and use of live plant collections for conservation. Biodiversity and Conservation, 20(2): 241-258.

RAUSCHKOLB, R. (2017). Does ex situ cultivation of rare plant species in botanical gardens lead to loss of adaptation to the wild? Unpublished Master's thesis, University of Tübingen.

RUCINSKA, A. \& PUCHALSKI, J. (2011). Comparative molecular studies on the genetic diversity of an ex situ garden collection and its source population of the critically endangered Polish endemic plant Cochlearia polonica E. Fröhlich. Biodiversity and Conservation, 20(2): 401-413.

SCBD (2010). Global Strategy for Plant Conservation. Updated Strategy 2011-2020. Secretariat of the Convention on Biological Diversity. Available online: www.cbd.int/gspc/about.shtml (accessed December 2013).

SCHAAL, B.B. \& LEVERICH, W.J. (2004). Population genetic issues in ex situ conservation. In: GUERRANT, E.O., HAVENS, K. \& MAUNDER, M. (eds) Ex Situ Plant Conservation: Supporting Species Survival in the Wild. Island Press, Washington, DC, pp. 267-285.

SCHOEN, D.J. \& BROWN, A.H.D. (2001). The conservation of wild plant species in seed banks. BioScience, 51(11): 960-966.

SCHOEN, D.J., DAVID, J.L. \& BATAILLON, T.M. (1998). Deleterious mutation accumulation and the regeneration of genetic resources. Proceedings of the National Academy of Sciences of the United States of America, 95(1): 394-399.

SCHRÖDER, R. \& PRASSE, R. (2013a). Cultivation and hybridization alter the germination behavior of native plants used in revegetation and restoration. Restoration Ecology, 21(6): 793-800.

SCHRÖDER, R. \& PRASSE, R. (2013b). From nursery into nature: A study on performance of cultivated varieties of native plants used in re-vegetation, their wild relatives and evolving wild $\times$ cultivar hybrids. Ecological Engineering, 60: 428-437.

SCHRÖDER, R., GRAF, M.D., JOCHUM, J., RODE, G. \& SCHEMMEL, J. (2013). Testing the effects of a regionalized seed production on the germination behavior of wild plant species. Ecological Restoration, 31(3): 295-301.

VITT, P. \& HAVENS, K. (2004). Integrating quantitative genetics into ex situ conservation and restoration practices. In: GUERRANT, E.O., HAVENS, K. \& MAUNDER, M. (eds) Ex Situ Plant Conservation: Supporting Species Survival in the Wild. Island Press, Washington, DC, pp. 286-304.

VOLIS, S. (2017). Conservation utility of botanic garden living collections: Setting a strategy and appropriate methodology. Plant Diversity, 39(6): 365-372.

VOLIS, S. \& BLECHER, M. (2010). Quasi in situ: A bridge between ex situ and in situ conservation of plants. Biodiversity and Conservation, 19(9): 2441-2454. 
WALKER, K.J., HODDER, K.H., BULLOCK, J.B. \& PYWELL, R.F. (2004). A Review of the Potential Effects of Seed Sowing for Habitat Re-creation on the Conservation of Introspecific Biodiversity. Defra Contract BD1447. Centre for Ecology and Hydrology, Monks Wood.

WALKER, E., MEIMBERG, H. \& KOLLMANN, J. (2014). Mixed evidence for the cultivar vigour hypothesis: The case of calcareous grassland forbs in a matrix of Festuca rubra. Ecological Engineering, 71: 301-307.

WIKIPEDIA (2018). Available online: https://en.wikipedia.org/wiki/Horticulture (accessed April 2018).

WILLAND, J.E., BAER, S.G. \& GIBSON, D.J. (2015). Propagule abundance and richness are equivalent or higher in communities restored with local ecotypes relative to cultivars of dominant species. Journal of Vegetation Science, 26(3): 421-430.

WILLI, Y., VAN BUSKIRK, J. \& HOFFMANN, A.A. (2006). Limits to the adaptive potential of small populations. Annual Review of Ecology, Evolution, and Systematics, 37: 433-458.

WILLIAMS, S.E. \& HOFFMAN, E.A. (2009). Minimizing genetic adaptation in captive breeding programs: A review. Biological Conservation, 142(11): 2388-2400.

WITZENBERGER, K.A. \& HOCHKIRCH, A. (2011). Ex situ conservation genetics: A review of molecular studies on the genetic consequences of captive breeding programmes for endangered animal species. Biodiversity and Conservation, 20(9): 1843-1861.

WYSE JACKSON, P.S. \& SUTHERLAND, L.A. (2000). International Agenda for Botanic Gardens in Conservation. Botanic Gardens Conservation International, Richmond.

ZHANG, J.J., YE, Q.G., YAO, X.H. \& HUANG, H.W. (2010). Spontaneous interspecific hybridization and patterns of pollen dispersal in ex situ populations of a tree species (Sinojackia xylocarpa) that is extinct in the wild. Conservation Biology, 24(1): 246-255.

ZOHARY, D. (2004). Unconscious selection and the evolution of domesticated plants. Economic Botany, 58(1): 5-10. 



\title{
CONSERVATION HEDGES - MODERN-DAY ARKS
}

\author{
Martin Gardner ${ }^{1}$, Tom Christian ${ }^{2}$, William Hinchliffe $e^{3} \&$ Robert Cubey ${ }^{4}$
}

\begin{abstract}
In May 2014, the first planting of the Royal Botanic Garden Edinburgh (RBGE) conservation hedge took place, when the Reverend Anne Brennan planted a tree which had originated as a cutting from the ancient and historic European yew, Taxus baccata, in the churchyard of her church at Fortingall, Perthshire. This is one of almost 2,000 plants that will eventually form a conservation hedge of significant scientific and conservation value. The International Conifer Conservation Programme (ICCP), based at RBGE, has actively sought other opportunities to establish conservation hedges via its network of 'safe sites', using a range of different conifer species. This initiative is being driven by the potential for relatively large numbers of genotypes from a single threatened species to be stored in a linear space. It is well established that seed banks have a great capacity to store large amounts of genetic diversity, so we should simply consider conservation hedges in a similar manner. These super-hedges cram relatively large amounts of genetic material into a small space, capturing a great range of wild traits and potentially contributing to the restoration of wild populations. To date, conservation hedges have been planted at five separate locations at RBGE's Edinburgh Garden as well as at four ICCP external 'safe sites'. Although this article focuses on the establishment of conservation hedges using conifers, we have also highlighted some conservation hedges that comprise non-coniferous species.
\end{abstract}

\section{INTRODUCTION}

If botanic gardens are going to have any valid claim to use their collections as a conservation genetic resource, then they need to be more than stamp collections of single individuals. Certainly, in the climate of reduced field work funding and the stifling effect of the Nagoya Protocol for transferring material, every opportunity needs to be taken with all available space being fully utilised to accommodate 'hard-won', naturally sourced plant material. After all, this is what underpins the vital research of botanic gardens and supports the wider, equally important remit of conserving plant biodiversity in the face of global environmental change and mass extinctions. The 35 ha site at the Royal Botanic Garden Edinburgh (RBGE) does not provide too many opportunities for planting trees but nowhere should be considered out of bounds for planting material of scientific and conservation significance - not even the perimeter hedge.

1. Martin Gardner is Coordinator of the International Conifer Conservation Programme (ICCP) at the Royal Botanic Garden Edinburgh.

Address: 20A Inverleith Row, Edinburgh, EH3 5LR, UK.

Email: mgardner@rbge.org.uk

2. Tom Christian is a Consulting Plantsman.

Address: West Lodge of Ballechin, Pitlochry, Perthshire, PH9 OLW, UK.

3. William Hinchliffe is an Arboriculturist at the Royal Botanic Garden Edinburgh.

Address: 20A Inverleith Row, Edinburgh, EH3 5LR, UK.

4. Robert Cubey is Plant Records Officer at the Royal Botanic Garden Edinburgh.

Address: as above 